\title{
Acacia courtii, a new species from eastern New South Wales (Acacia sect. Juliflorae: Fabaceae)
}

\author{
Mary D. Tindale and Clare Herscovitch
}

\begin{abstract}
Tindale, Mary D. and Herscovitch, Clare (Royal Botanic Gardens, Sydney, N.S.W. 2000) 1990. Acacia courtii, a new species from eastern New South Wales (Acacia sect. Juliflorae: Fabaceae). Telopea 4(1): 115-119. A new species of Acacia with a restricted distribution on the North Coast of New South Wales is described, namely A. courtii (sect. Juliflorae). A map is provided showing its known distribution. This species is illustrated and its affinities discussed. A key is provided to this species and its ally Acacia orites Pedley.
\end{abstract}

\section{Introduction}

A new species of Acacia is described, prior to the forthcoming volume 2 of the Flora of New South Wales.

\section{Taxonomy}

The terminology of shapes in the specific description is that defined by Lee (1948: 144).

Acacia courtii Tind. et Herscovitch, sp. nov.

Acacia oritidi Pedley affinis, a qua differt calycibus $0.5-0.8 \mathrm{~mm}$ longis, corollis $1.8-2.3$ $\mathrm{mm}$ longis, leguminibus crassis lignosisque, seminibus majoribus, $5.6-7.7 \mathrm{~mm}$ longis (arillo non incluso), 2.3-3.0 mm latis, nervis minoribus phyllodiorum dense anastomosantibus.

Holotypus: NeW SOUTH WALES: On roadside, Captain Cook Bicentenary Rd., North Brother Mtn., $27 \mathrm{~km} \mathrm{SW}$ of Port Macquarie, in dry sclerophyll forest, rocky soil, altitude $40 \mathrm{~m}$, small tree $7 \mathrm{~m}$ tall; fruit dark grey; associated with Eucalyptus acmenoides, E. propinqua, E. intermedia. 'Leaves' with red margins, somewhat glaucous and of weeping habit, K.J. Phillis, for A.G. Floyd 1157, 16.xi.1978 (NSW). Isotypi: BRI, CANB, K, Coffs Harbour (N.S.W.) Forestry Herbarium.

Tall shrub or weeping tree 7-20 m high; trunk d.b.h. to $50 \mathrm{~cm}$; foliage pendulous, often tinged pink to purplish red in rapidly growing tips; bark smooth and grey, later black and furrowed. Branchlets slender, flexible, angled, becoming terete, pale tawny or pale green, glabrous, often slightly to moderately glaucous, bark sometimes slightly flaky in patches, becoming mottled then dark maroon-brown, often with fawn-brown lenticels. Phyllodes borne singly, green, dull, flattened, linear, (5-)11-18 cm long, 4.5-8.5(-12) $\mathrm{mm}$ wide, $1 / \mathrm{b}=(10-) 16-26(-33)$, widest at or near the middle, subcoriaceous, glabrous, tapered gradually towards apex and base; nerves prominent and pale with one main central nerve and on either side 1-3 longitudinal nerves which are slightly more or no more prominent than the longitudinal anastomosing minor nerves, the $1 / \mathrm{b}$ of the areoles $>10$; margins red (when fresh), yellowish brown or light purplish brown (when dried); apical mucro attenuated, slightly oblique or hooked, to $1.2 \mathrm{~mm}$ long, bearing a minute orbicular gland; basal gland of phyllode solitary, adaxial, $0.5-0.7 \mathrm{~mm}$ 
long, (0.1-)0.5-3.9 mm above the pulvinus, orbicular to \pm oblong, the rim orange or yellow-tawny, glabrous, distinctly raised above the margin or \pm sunken; pulvinus light tawny to reddish brown, glabrous, often glaucous in the furrows, $1.0-4.0 \mathrm{~mm}$ long, 1.0-3.0 mm wide. Stipules caducous, inconspicuous, c. $0.4 \mathrm{~mm}$ long, c. $0.3 \mathrm{~mm}$ wide at the base, deltate, orange-brown, scurfy. Inflorescence pale yellow, spicate, single or paired in the phyllode axils (rarely non-axillary), 3.0-6.5 cm long after anthesis, c. 5 mm wide; flowers 55-78, compactly arranged in bud, reduced to 25-44 flowers and becoming distant as the rhachis elongates, the flowers in clusters of 3 or 4 along the rhachis; rhachis and peduncle slender, tawny, glabrous, often slightly glaucous, longitudinally wrinkled when dried, probably terete when fresh, c. $0.6 \mathrm{~mm}$ diam.; peduncle 3-5 mm long; bracts apparently 2 per inflorescence, imbricate, papery, brown or brownish orange, narrow deltate with incurled margins, fimbriate but otherwise glabrous, $1.0-2.4 \mathrm{~mm}$ long; bracteoles $(0.65-) 0.7(-0.85) \mathrm{mm}$ long, peltate or scutelliform, the claw (0.25-)0.4-0.5 mm long, comparatively wide, the margins densely fimbriate; lamina flat or angled inwards, $0.4-0.6 \mathrm{~mm}$ long, \pm broad-ovate, membranous, the surface with spreading white hairs or more usually glabrous, the margin fimbriate with hyaline hairs c. $0.1 \mathrm{~mm}$ long. Flowers 4 -merous, rounded in bud. Calyx pale, membranous, $0.5-0.8 \mathrm{~mm}$ long, $1.2-1.5 \mathrm{~mm}$ wide, dissected for $1 / 6-1 / 3$ of its length into blunt, broadly deltate, glabrous lobes, often slightly keeled, the sinuses broadly obtuse, the margin fringed with minute white hairs, the tube covered with spreading white hairs $0.1-0.2 \mathrm{~mm}$ long. Corolla pale yellow to almost white, delicate, glabrous, 3-3.5 times the length of the calyx, $1.8-2.3 \mathrm{~mm}$ long, dissected for $1 / 2-3 / 5$ of its length; petals elliptical, relatively broad, $1 / b=2$, mostly the margins slightly incurved towards the papillose apex. Stamens 3.0-4.8 $\mathrm{mm}$ long. Ovary sessile, ellipsoid or \pm oblong, c. $0.8 \mathrm{~mm}$ long, c. $0.4 \mathrm{~mm}$ diam., pale yellowish orange, densely villous with white tapering hairs $0.25-0.3 \mathrm{~mm}$ long; style $3.0-3.3(-4.2) \mathrm{mm}$ long. Legumes straight or falcate, linear, contracted slightly between the seeds, woody, thick, longitudinally wrinkled when dried, probably terete when fresh, (7.5-) $12.5-18.0 \mathrm{~cm}$ long, (3.0-)3.5-4.0 mm wide, light brown to brown, glabrous, occasionally slightly glaucous; margins pale, shortly tapered to an acute apex and to the base; stalk c. $5 \mathrm{~mm}$ long, sparsely clothed with white, appressed hairs c. $0.2 \mathrm{~mm}$ long. Seeds (6-)8-11 per legume, elongated, ellipsoid and often laterally compressed, longitudinally placed in the legume, glossy, brown, with a lighter brown peripheral ridge, 5.6-7.7 mm long, 2.3-3.0 mm wide, $2.3-2.6 \mathrm{~mm}$ thick; pleurogram a thin dark line, narrowly U-shaped, open towards the hilum; areole elongated, $4.8-6.3 \mathrm{~mm}$ long, $1.3-1.6 \mathrm{~mm}$ wide; funicle golden orange when dried, filiform, lightly folded 4-8 times over the acentral basal aril. Flowering: November-January. Fruiting: November, legume probably taking about a year to mature (Figure 1).

Distribution: New South WALEs: Mid-north Coast: only known from North Brother Mtn, Camden Haven State Forest, and Middle Brother Mtn, Middle Brother State Forest (Figure 2).

HABITAT: Mostly occurring on dry, rocky, north-west- to west-facing mountain slopes in shallow soils, on microgranite, in mixed dry sclerophyll forest (White Mahogany and Grey Gum), at altitudes of $40-300 \mathrm{~m}$.

SPECIMENS EXAMINED: NeW SOUTH WALES: North Coast: Laurieton, Captain Cook Bicentenary Rd., near Camden Haven State Forest, $31^{\circ} 38^{\prime}$ S, $152^{\circ} 46^{\prime}$ E, K.J. Phillis NSW 221504, 26.i.1981 (NSW); Compartment 138 , Middle Brother State Forest, $31^{\circ} 41^{\prime} \mathrm{S}, 152^{\circ} 42^{\prime} \mathrm{E}$, wood voucher for phytochemical survey, K.J. Phillis NSW 145771, 25.i.1981 (AD, B, BM, CANB, CBG, K, L, MEL, MO, NSW, NE, PERTH, TL, UC, US); Devils Hole, Middle Brother Mountain, A.G. Floyd 913, 27.iv.1978 (NSW).

The specific epithet honours Mr Arthur B. Court who retired in January 1989 as 


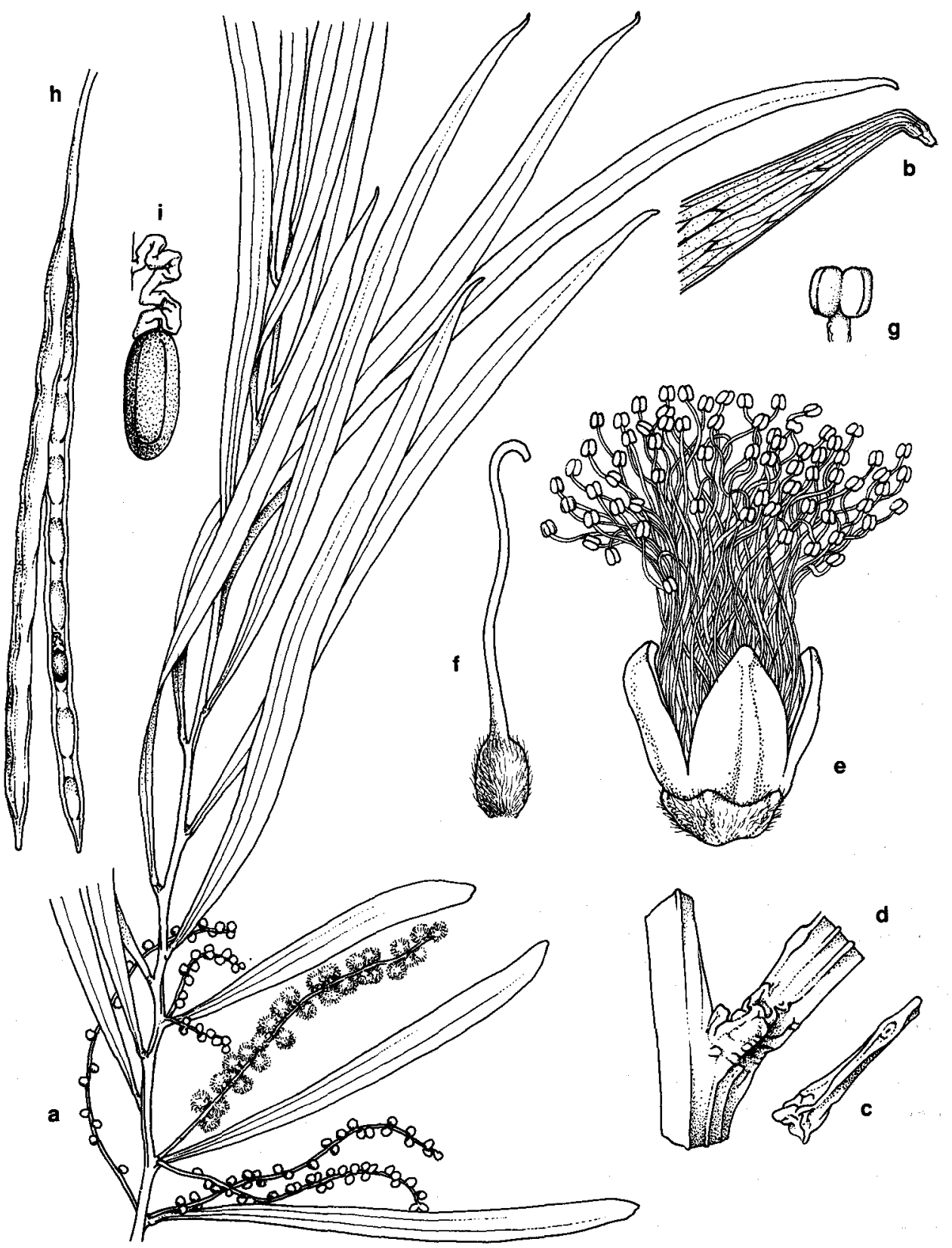

Figure 1. Acacia courtii. a. habit, with phyllodes and spicate inflorescences $\left(x^{2 / 3}\right)$. b. apex of phyllode $\left(x 4^{2 / 3}\right)$. c. pulvinus, side view $\left(x 4^{2 / 3}\right)$. d. base of phyllode, with pulvinus and gland $(x$ $\left.4^{2 / 3}\right)$. e. flower $\left(x 13^{1 / 3}\right)$. f. gynoecium $\left(x 13^{1 / 3}\right)$. g. anther $\left(x 3^{1 / 3}\right)$. h. legume $\left(x^{2 / 3}\right)$. i. seed $\left(x 2^{1 / 3}\right)$. Vouchers: a-d, h-i, K.J. Phillis NSW 145771; e-g, K.J. Phillis (AGF 1157). Del. R.A. Roden. 




Figure 2. Distribution of $A$. courtii.

Assistant Director, Australian National Botanic Gardens, Canberra, A.C.T. He is revising the group of Australian Acacia species to which $A$. courtii belongs.

A. courtii is closely allied to A. orites Pedley (1964: 32-33, 1978: 167), both of which belong to sect. Juliflorae subseries Tetramerae. Most species of the latter subseries occur in eastern Australia. The flowers of the Tetramerae are 4-merous and the legumes (with one exception) elongated, narrow and \pm constricted between the seeds. A. courtii has a very restricted distribution on Middle Brother and North Brother Mountains on the mid-North Coast of New South Wales, whereas $A$. orites is confined to the edge of rainforests and in wet sclerophyll forests with high rainfall at $600-900 \mathrm{~m}$ altitude on the Mount Warning shield volcano in far north-eastern New South Wales and southeastern Queensland.

We would recommend a Conservation Code of $2 \mathrm{~V}$ (vulnerable) according to the criteria used by Briggs and Leigh (1988).

Key to $A$. courtii and $A$. orites

1 Phyllodes with densely anastomosing nerves. Legumes thick, woody, $7.5-18.0 \mathrm{~cm}$ long. Seeds (not including the aril) $5.6-7.7 \mathrm{~mm}$ long, 2.3-3.0 mm wide. Calyces 0.5-0.8 mm long. Corollas $1.8-2.3 \mathrm{~mm}$ long. Flowering November-January

A. courtii

1* Phyllodes with sparsely anastomosing nerves. Legumes thinly coriaceous, 6.5-11.0 $\mathrm{cm}$ long. Seeds (not including the aril) $2.5-4.0 \mathrm{~mm}$ long, $1.7-2.0 \mathrm{~mm}$ wide. Calyces c. $0.5 \mathrm{~mm}$ long. Corollas $1.5-2.0 \mathrm{~mm}$ long. Flowering August-October 


\section{Acknowledgements}

We acknowledge a grant from the Australian Biological Resources Study to Mary Tindale in 1983-1984, when Clare Herscovitch provided research assistance in this Acacia project. During a grant from ABRS in 1989 Miss S. Armitage prepared Figure 2 and undertook the word-processing of this manuscript. In $1990 \mathrm{Mr}$. Kodela prepared the final word-processing of this paper during a grant from the Royal Botanic Gardens Research Fund.

Our thanks are due to Dr R.W. Johnson, Director, Queensland Herbarium, for the loan of specimens of $A$. orites, as well as to Mr A.G. Floyd and Dr K.J. Phillis who drew our attention to A. courtii. Messrs. A.B. Court and A.G. Floyd also provided helpful suggestions regarding our manuscript.

Grateful acknowledgement is made to Dr L.A.S. Johnson for providing funds, when he was Director, Royal Botanic Gardens Sydney, for the plate of $A$. courtii drawn by $\mathrm{Mr}$ R.A. Roden. We also wish to thank Dr Johnson for checking the Latin diagnosis prepared by Mary Tindale.

\section{References}

Briggs, J.D. \& Leigh, J.H. (1988) Rare or Threatened Australian Plants. Special Publication Australian National Parks and Wildlife Service 14.

Lee, A.T. (1948) The genus Swainsona. Contr. New South Wales Natl. Herb. 1: 131-271.

Pedley, L. (1964) Notes on Acacia, chiefly from Queensland II. Proc. Roy. Soc. Queensland 75: 29-35.

Pedley, L. (1978) A revision of Acacia Mill. in Queensland. Austrobaileya 1: 75-234.

Manuscript received 28 November 1989

Manuscript accepted 1 May 1990 